\title{
Taxable and Tax-deferred Investing with the Limited Use of Losses
}

Fischer, Marcel; Gallmeyer, Michael

\author{
Document Version \\ Published in: \\ Review of Finance \\ DOI: \\ $10.1093 /$ rof/rfw047 \\ Publication date: \\ 2017 \\ License \\ Unspecified
}

Accepted author manuscript

Citation for published version (APA):

Fischer, M., \& Gallmeyer, M. (2017). Taxable and Tax-deferred Investing with the Limited Use of Losses.

Review of Finance, 21(5), 1847-1873. https://doi.org/10.1093/rof/rfw047

Link to publication in CBS Research Portal

\section{General rights}

Copyright and moral rights for the publications made accessible in the public portal are retained by the authors and/or other copyright owners and it is a condition of accessing publications that users recognise and abide by the legal requirements associated with these rights.

\section{Take down policy}

If you believe that this document breaches copyright please contact us (research.lib@cbs.dk) providing details, and we will remove access to the work immediately and investigate your claim.

Download date: 26. Apr. 2023 


\section{Taxable and Tax-Deferred Investing with the Limited Use of Losses}

\section{Marcel Fischer and Michael Gallmeyer}

Journal article (Post print version)

This is a pre-copyedited, author-produced PDF of an article accepted for publication in Review of Finance following peer review. The version of record: Taxable and TaxDeferred Investing with the Limited Use of Losses. / Fischer, Marcel; Gallmeyer, Michael. In: Review of Finance, 25.09.2016, is available online at:

http://dx.doi.org/10.1093/rof/rfw047

Uploaded to Research@CBS: October २०16 


\title{
Taxable and Tax-Deferred Investing with the
}

\section{Limited Use of Losses}

\author{
MARCEL FISCHER $^{1}$ and MICHAEL GALLMEYER ${ }^{2}$ \\ ${ }^{1}$ Copenhagen Business School and University of Konstanz; ${ }^{2}$ McIntire School of \\ Commerce at the University of Virginia
}

\begin{abstract}
We study the impact of the different tax treatment of capital gains and losses on the optimal location of assets in taxable and tax-deferred accounts. The classical result of Black (1980) and Tepper (1981) suggests that investors should follow a strict pecking-order asset location rule and hold those assets that are subject to the highest tax rate preferentially in tax-deferred accounts. We show that with the different tax treatment of realized gains and losses, only tax-efficient equity mutual funds are optimally held in taxable accounts whereas mutual funds with average tax-(in)efficiency are preferentially
\end{abstract}

\footnotetext{
${ }^{*}$ We would like to thank John Christensen, Christian Dorion, Bjarne Astrup Jensen, Robert Korajczyk, Claus Munk, Clemens Sialm, Michael Stamos, Carsten Sørensen, Harold Zhang, participants at the German Finance Association Annual Meeting, the SFS Cavalcade, the Arne Ryde Workshop in Financial Economics at Lund University, the Gutmann Center Symposium at the WU Vienna, and seminar participants at the Universities of Copenhagen, Frankfurt, HEC Montréal, Regensburg, and Copenhagen Business School for helpful comments and discussion. We are particularly indebted to an anonymous referee and Bernard Dumas (the editor) whose comments greatly improved our manuscript.This paper uses data from the Eurosystem Household Finance and Consumption Survey. The results published and the related observations and analysis may not correspond to results or analysis of the data producers. We thank Larissa Zimmermann for excellent research assistance with the Eurosystem Household Finance and Consumption Survey data from the European Central Bank and Andreas Kühn for setting up our parallel computing environment. Marcel Fischer gratefully acknowledges financial support from the Pension Research Center at Copenhagen Business School. Michael Gallmeyer acknowledges support from the McIntire Center for Financial Innovation. All errors are our own. An earlier version of the paper circulated under the title "Are Bonds Desirable in Tax-Deferred Accounts?"
} 
held in tax-deferred accounts.

Keywords: portfolio choice, limited use of capital losses, tax-deferred investing, asset location

JEL Classification: G11, H24

\section{Introduction}

The tax treatment of an individual investor's trading gains and losses is an important factor influencing household portfolio choice. While trading in conventional taxable accounts can lead to realized taxable gains, trades in tax-deferred accounts are not taxed. As tax laws limit contributions into and early withdrawals out of tax-deferred accounts, individual investors not only have to decide which assets to hold (the asset allocation problem), but also in which account to hold them (the asset location problem). Given tax-deferred accounts are typically retirement savings vehicles, tax considerations can be important drivers of retirement savings decisions.

In early work, Black (1980) and Tepper (1981) show that, with unlimited borrowing, the ability to short sell, and an equal tax treatment of capital gains and losses, definedbenefit pension plans should only hold risk-free assets in their portfolios. By introducing the asset location problem into a household portfolio choice problem, Shoven and Sialm (1998) argue that households should prefer these assets in their tax-deferred accounts. However, many private investors hold substantial amounts of equity in their tax-deferred retirement accounts (Bergstresser and Poterba, 2004). According to the 2010 Survey of Consumer Finances, 85.9 percent of all families investing in equity have equity holdings in tax-deferred accounts and 42.3 percent of all equity was held in tax-deferred accounts. This discrepancy between theory and behavior is commonly called the asset location puzzle (Amromin, 2003).

Later research has focused on introducing frictions in the Tepper-Black setting to break the strict preference for risk-free assets in a tax-deferred account. These frictions include 
the tax-inefficiency of actively managed mutual funds (Shoven and Sialm, 2003), stochastic labor income and/or wealth shocks (Amromin, 2003; Dammon et al., 2004; Garlappi and Huang, 2006; Huang, 2008), trading restrictions such as short-selling and borrowing constraints (Garlappi and Huang, 2006), the Roth-Conversion and Re-characterization option (Dammon et al., 2011), and differential stock market participation costs in taxable and tax-deferred accounts (Zhou, 2012). Our paper contributes to this line of research by showing that the tax code itself, namely the different tax treatment of capital gains and losses, can help explain the asset location puzzle.

For investors trading in tax systems with an equal tax treatment of capital gains and losses who face no trading constraints, Huang (2008) generalizes the Tepper-Black results to a dynamic setting and shows that investors prefer risk-free assets in their tax-deferred accounts. However, this result does not generalize to a feature common in most tax systems, namely that capital gains and losses are subject to different tax treatments. The different tax treatment of capital gains and losses causes two additional opposing effects influencing the asset location decision. First, a tax loss is a less attractive compensation than an immediate tax rebate payment since it leaves the investor with the full immediate downside risk, thus making the risk return profile of equity held in taxable accounts less desirable. Hence, it increases the desirability of holding equity in a tax-deferred account. Second, the opportunity to be compensated with a tax loss carry-forward improves the set of attainable future risk-return profiles in a taxable account. In particular, loss carryforward from previous trading thus increases the desirability to hold equity in a taxable account.

Our work generalizes Shoven and Sialm (2003) by showing that not only the taxefficiency of stock portfolios, but also the different tax treatment of capital gains and losses affects the optimal location of assets to taxable and tax-deferred accounts. Specifically, we show that even if equity is taxed at a lower rate than risk-free assets, investors might optimally hold equity mutual funds in tax-deferred accounts when capital gains and losses are subject to different tax treatment.

While the impact of the opportunity to invest in a tax-deferred account has been extensively studied (Shoven and Sialm, 1998, 2003; Dammon et al., 2004; Poterba et al., 2004; 
Garlappi and Huang, 2006; Huang, 2008; Gomes et al., 2009; Zhou, 2009), only limited guidance is available to investors who face tax systems where capital gains and losses are subject to different tax treatments. In a single taxable account setting, Marekwica (2012) and Ehling et al. (2015) argue that a differential tax treatment of capital gains and losses can have a large impact on optimal portfolio choice.

Our contribution to the literature is two-fold. First, to the best of our knowledge, we are the first to study the impact of the differential taxation of capital gains and losses on the asset location decision. Second, we show that with differential tax treatment of capital losses the optimal location of assets depends on the investor's tax rates on capital gains, dividends, and interest as well as the tax-efficiency of the stock portfolio.

The remainder of this paper proceeds as follows. Section 2 introduces our life cycle model and discusses portfolio implications of the different tax treatment of capital gains and losses. Section 3 provides numerical evidence on the impact of the limited use of losses for the optimal location of assets to taxable and tax-deferred accounts. Section 4 demonstrates how tax-timing considerations affect the optimal asset location decision. Section 5 provides international evidence. Section 6 concludes. The technical details on how we solve the optimization problem are provided in the Appendix.

\section{The Model}

\subsection{ASSET RETURNS AND TAXATION}

Since their introduction, equity mutual funds have increased in popularity among private investors as these investment vehicles allow investing in a diversified stock portfolio even when the amount invested is relatively small. We therefore assume that investors in our model hold equity through a well-diversified equity mutual fund. ${ }^{1}$ We consider a market in which investors have access to a diversified equity mutual fund and a risk-free money market account. The constant pre-tax risk-free return on the money market account is

\footnotetext{
1 According to the 2010 Survey of Consumer Finances, the share of households with direct stock holdings or indirect stock holdings through equity mutual funds was $47.0 \%$ in 2010 . The share of households with direct stock holdings was only $17.8 \%$ and concentrates among high net worth households.
} 
denoted by $r$. The return on the equity mutual fund is assumed to be binomially distributed ${ }^{2}$ serially independent, and is assumed to come with an expected pre-tax capital gain of $\mu$, and a standard deviation of $\sigma$. It further distributes a constant pre-tax dividend rate of $d$. The tax applicable to capital gains in taxable accounts is denoted by $\tau_{g}$. The tax rate on dividends is denoted by $\tau_{d}$. Interest and other income is taxed at a rate of $\tau_{i}$. For early withdrawals from tax-deferred accounts prior to retirement age we follow Dammon et al. (2004) and assume that a penalty tax of $\tau_{p}$ applies.

\subsection{FULL AND LIMITED USE OF LOSSES}

Following Ehling et al. (2015), we refer to the tax systems with equal and different tax treatment of capital gains and losses as tax system with full and limited use of losses, respectively, throughout. Definitions 1 and 2 highlight the differences between them:

Definition 1 Full use of losses. In a tax system with the full use of losses, realized gains and losses are subject to equal tax treatment. In particular, if an investor realizes a capital loss, he receives an immediate cash-back tax rebate payment.

A tax system with the full use of losses is widely assumed in the portfolio choice literature in the presence of taxes (Dammon et al., 2001, 2004; Amromin, 2003; Shoven and Sialm, 2003; DeMiguel and Uppal, 2005; Gallmeyer et al., 2006; Garlappi and Huang, 2006; Huang, 2008; Gomes et al., 2009; Zhou, 2009). However in reality, realized losses do not result in immediate tax rebate payments in most tax systems around the world.

Definition 2 Limited use of losses. In a tax system with the limited use of losses, an investor is compensated for realized capital losses with a tax loss carry-forward that can be used to offset realized capital gains. Any loss that is not used immediately can be carried over indefinitely to offset future gains.

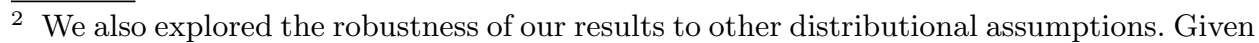
that our results are robust to these changes, we do not report them here.
} 
In contrast to a full use of losses tax system, tax authorities do not share the downside risk resulting from a capital loss with investors under the limited use of losses. Instead, investors receive a tax loss carry-forward (henceforth TLCF) that can be used to offset future capital gains and can be carried forward indefinitely. ${ }^{3}$ The TLCF is a less attractive compensation than an immediate tax rebate payment for two reasons. First, in contrast to a tax rebate payment, the TLCF cannot be invested and thus does not earn any profits. Second, the TLCF carries the risk of being forfeited if it is not used by the end of the investor's life. In the following, we describe the tax treatment of capital gains and losses in the tax system with the limited use of losses in more detail.

We denote the capital gain realized at time $t$ in a taxable account by $G_{t}$. A TLCF that is carried over from period $t$ to $t+1$ is defined as $L_{t} \geq 0$. The taxable profit $T_{t}$ from an investor's trading at time $t$ that is subject to capital gains tax is then given by

$$
T_{t}=\max \left(G_{t}-L_{t-1} ; 0\right)
$$

Equation (1) shows that - in contrast to tax systems with equal tax treatment of capital gains and losses - an investor bears the full downside risk in case of a capital loss. Net capital losses can be carried forward indefinitely. Thus, the TLCF $L_{t}$ that can be carried over from period $t$ to period $t+1$ is given by

$$
L_{t}=T_{t}-G_{t}+L_{t-1}
$$

A TLCF that has not been used by the end of the investor's life is forfeited.

The limited use of losses carries two important disadvantages relative to the full use of losses. First, the TLCF cannot be consumed or invested. It therefore does not earn any profits. Second, a TLCF which is not used until the end of the investor's life is forfeited. Both these disadvantages provide incentives for holding equity in tax-deferred accounts. In the next subsection, we argue that it is sufficient to break a replication argument that is often used to argue in favor of a pecking-order asset location rule that preferentially locates bonds in tax-deferred accounts. Our numerical analysis in sections 3 and 4 shows

\footnotetext{
3 For simplicity, we follow Shoven and Sialm (2003) and abstract away from the institutional detail that under current U.S. tax law mutual funds are prohibited from distributing losses to their investors.
} 
that it is also a sufficient condition for holding stocks in tax-deferred environments for reasonable parameter assumptions.

\subsection{THE REPLICATION ARGUMENT}

Here we motivate in a simple one-period example that the limited use of losses can break the replication argument used by Black (1980), Tepper (1981), and Huang (2008) that argues in favor of a pecking-order asset location strategy that preferentially places riskfree assets in tax-deferred accounts. The after-tax return on the risk-free money market account in the taxable and the tax-deferred account is given by $r_{T}=r \cdot\left(1-\tau_{i}\right)$ and $r_{D}=$ $r$, respectively. When $g$ denotes the stochastic capital gain on the risky mutual fund investment and the mutual fund does not pay out dividends, the after-tax return on the mutual fund investment in the taxable and the tax-deferred account with the full use of losses is

$$
\begin{aligned}
& r_{T, S}=g \cdot\left(1-\tau_{g}\right) \\
& r_{D, S}=g
\end{aligned}
$$

With the limited use of losses, the after-tax return on the equity mutual fund in a taxable account depends on whether $g$ is positive or not:

$$
r_{T, S}=\left\{\begin{array}{cc}
\left(1-\tau_{g}\right) \cdot g & \text { if } g \geq 0 \\
g & \text { if } g<0
\end{array}\right.
$$

That is, with the limited use of losses, the investor still faces capital gains taxation in case of a capital gain. However, in contrast to the setting with the full use of losses, the investor no longer receives a tax rebate payment in case of a loss, but only a TLCF, which is a less attractive compensation than an immediate tax rebate payment. Given that the risk-return characteristics of tax-deferred equity and both taxable and tax-deferred money market investments are unaffected by the limited use of losses, the less attractive tax treatment of equity in the taxable account provides an incentive for holding equity in tax-deferred environments. 
In the remainder of this section, we show that the different tax treatment of capital gains and losses is sufficient to break the replication argument. The replication argument used by Black (1980), Tepper (1981), and Huang (2008) focuses on a one-period investment horizon and asks how many dollars have to be invested in a taxable account in a given asset to attain the same level of wealth after taxes as investing one dollar in the same asset in a tax-deferred account.

One dollar invested in the risk-free asset in a tax-deferred account gives the investor a level of final wealth of $1+r$. To attain the same level of total final wealth in a taxable account, the investor has to invest $\frac{1+r}{1+\left(1-\tau_{i}\right) r}$ dollars. For $\tau_{i}>0$, the investor thus has to invest more than one dollar to make up for the taxation of interest. Similarly, with the full use of losses - as assumed in the work of Black (1980), Tepper (1981), and Huang (2008) - one dollar invested in the mutual fund in a tax-deferred account yields a level of total final wealth of $1+g$. To attain the same level of final wealth in a taxable account, the investor has to hold $\frac{1}{1-\tau_{g}}$ dollars in the mutual fund and $\frac{-\tau_{g}}{\left(1-\tau_{g}\right)\left(1+\left(1-\tau_{i}\right) r\right)}$ dollars in the risk-free asset as this portfolio yields a level of total final wealth of

$$
\frac{1}{1-\tau_{g}}\left(1+\left(1-\tau_{g}\right) g\right)+\frac{-\tau_{g}}{\left(1-\tau_{g}\right)\left(1+\left(1-\tau_{i}\right) r\right)}\left(1+\left(1-\tau_{i}\right) r\right)=1+g
$$

Consequently, replicating the payoff of one tax-deferred dollar in the risk-free asset costs $\frac{1+r}{1+\left(1-\tau_{i}\right) r}$ dollars, whereas replicating the payoff of one tax-deferred dollar in the mutual fund costs

$$
\frac{1}{1-\tau_{g}}-\frac{\tau_{g}}{\left(1-\tau_{g}\right)\left(1+\left(1-\tau_{i}\right) r\right)}=\frac{1+\left(1-\tau_{i}\right) r-\tau_{g}}{\left(1-\tau_{g}\right)\left(1+\left(1-\tau_{i}\right) r\right)}
$$

dollars. To maximize their level of total final wealth, investors should preferentially hold the asset with the higher replication cost in the tax-deferred account. The difference between the two assets' replication costs is given by

$$
\frac{1+r}{1+\left(1-\tau_{i}\right) r}-\frac{1+\left(1-\tau_{i}\right) r-\tau_{g}}{\left(1-\tau_{g}\right)\left(1+\left(1-\tau_{i}\right) r\right)}=\frac{r\left(\tau_{i}-\tau_{g}\right)}{\left(1-\tau_{g}\right)\left(1+\left(1-\tau_{i}\right) r\right)} .
$$

This term is positive if $\tau_{i}>\tau_{g}$. That is, if the tax rate on interest exceeds that on capital gains - as is the case under current U.S. and many other countries' tax laws - the risk-free asset's replication costs are higher, and it is therefore preferentially held in a tax-deferred 
account, whereas the mutual fund is preferentially held in the taxable account. ${ }^{4}$ The replication argument thus implies a pecking-order asset location strategy that allocates the risk-free asset to the tax-deferred account and only allocates risk-free investments to the taxable account if the entire tax-deferred wealth is fully invested in that asset.

However, the replication argument heavily relies on the assumption that the full use of losses applies. With the limited use of losses, the replication argument breaks down. It is no longer possible to replicate the final wealth after taxes from an investment of one taxdeferred dollar in a mutual fund in a taxable account. Whereas for $g \geq 0$, the replicating portfolio of holding $\frac{1}{1-\tau_{g}}$ dollars in the mutual fund and $\frac{-\tau_{g}}{\left(1-\tau_{g}\right)\left(1+\left(1-\tau_{i}\right) r\right)}$ dollars in the risk-free asset still generates a level of total final wealth of $1+g$; for $g<0$ it leaves the investor with $1+\frac{g}{1-\tau_{g}}$ dollars, reflecting that from Equation (5), capital gains and losses are subject to a different tax treatment.

For $g<0$, the replicating portfolio only consists of one unit of the mutual fund, leaving the investor with $1+g$ dollars in case that it indeed turns out that $g<0$. For $g \geq 0$, however, the investor is left with only $1+g\left(1-\tau_{g}\right)$ dollars. In other words, the investor is no longer able to perfectly replicate the outcome of a tax-deferred dollar of wealth invested in the mutual fund in a taxable environment as this would require ex-ante knowledge about whether $g \geq 0$ or $g<0$. The replication strategy thus breaks down.

In sections 3 and 4 , we demonstrate that for reasonable parameter assumptions, it can be optimal to preferentially hold equity mutual funds in tax-deferred accounts or to hold mixed portfolios in both accounts under the limited use of losses.

\subsection{OPTIMIZATION PROBLEM}

We consider an economy consisting of investors living for at most $T$ years that can only trade at time $t=0,1, \ldots, T$ and retire at time $J . F(t)$ denotes the probability that the investor is still alive through period $t(t \leq T)$. Investors in that economy derive utility from the consumption of a single good and have CRRA-utility with parameter of risk-aversion $\gamma \in[0, \infty)$.

\footnotetext{
$\overline{4}$ Huang $(2008)$ shows that the replication argument can be generalized to mutual funds
} that pay out dividends. 
As shown in Constantinides (1983), investors endowed with unrealized capital losses should realize these losses immediately when trading in a tax system with the full use of losses. Gallmeyer and Srivastava (2011) and Marekwica (2012) show that realizing losses immediately remains optimal in a setting with the limited use of losses. Intuitively, this is because realizing the tax loss makes it more flexible in terms of future use. In particular, a realized tax loss from one share can be used to offset future gains in a different number of shares.

Investors endowed with unrealized gains, however, face a tradeoff between postponing the tax payment associated with the realization of their gains and diversifying their portfolios. Following Dammon et al. (2001), Dammon et al. (2004), Gallmeyer et al. (2006), and Ehling et al. (2015), we do not differentiate between long-term and short-term capital gains, and assume that the investor's tax basis used for computing realized capital gains is the weighted average of her historical purchase prices. Even though under current U.S. tax law investors can choose to sell the shares with the lowest level of unrealized gains first and thereby potentially postpone the taxation of more gains, solving for the optimal consumption-investment strategy over the life cycle in such a setting becomes numerically intractable. Moreover, DeMiguel and Uppal (2005) show that certainty equivalent wealth losses from using the average instead of the exact share identification basis rule are very small.

With $S_{t_{+}}$, we denote the number of shares the investor holds in a taxable account from time $t$ to $t+1$. $P_{t}$ is the price per share at time $t$. We assume that the equity mutual fund follows the recommendation in Constantinides (1983) and realizes losses immediately. Furthermore, it realizes a fraction $\nu \in[0,1]$ of unrealized capital gains to adjust its portfolio to circumstances. $\nu=1$ corresponds to a case where the fund realizes all gains periodically, which is equivalent to considering a setting without tax-timing option where all capital gains are subject to mark-to-market taxation. $\nu<1$ corresponds to a setting where the mutual fund makes use of the tax-timing option. The case $\nu=0$ implies that the mutual fund's trading strategy never imposes a tax burden on the investor and that the investor can fully exploit the tax-timing option. The parameter $\nu$ is determined by the tax-efficiency 
of the equity mutual fund's trading strategy. We therefore vary $\nu$ throughout section 4 to demonstrate its impact on optimal asset location decisions.

By $P_{t_{-}}^{*}$ we denote the investor's historical purchase price (tax basis) of the equity mutual fund in the taxable account at time $t$ after realization of losses and a fraction $\nu$ of the investor's unrealized gains, but before realization of further gains. $P_{t_{+}}^{*}$ is the investor's tax basis after trading at time $t . S_{t_{-}}$is the number of shares the investor holds at time $t$ after realization of losses and a fraction $\nu$ of unrealized gains, but prior to realization of further capital gains and purchases of new shares. ${ }^{5}$

The number of shares held after realization of losses and a fraction $\nu$ of unrealized capital gains but prior to realization of further gains in the taxable account is given by

$$
S_{t_{-}}=\left\{\begin{array}{cl}
0 & \text { if } P_{t_{-}}^{*} \geq P_{t} \\
(1-\nu) \cdot S_{t-1_{+}} & \text {if } P_{t_{-}}^{*}<P_{t} .
\end{array}\right.
$$

The investor's tax basis $P_{t_{-}}^{*}$ after realization of losses and a fraction $\nu$ of unrealized capital gains in the taxable account is given by

$$
P_{t_{-}}^{*}=\left\{\begin{array}{cl}
P_{t} & \text { if } P_{t-1_{+}}^{*} \geq P_{t} \\
P_{t-1_{+}}^{*} & \text { if } P_{t-1_{+}}^{*}<P_{t} .
\end{array}\right.
$$

The gain or loss from realizing losses or a fraction $\nu$ of unrealized capital gains is given by

$$
G_{t_{-}}=\left\{\begin{array}{cl}
S_{t-1_{+}} \cdot\left(P_{t}-P_{t_{-}}^{*}\right) & \text { if } P_{t-1_{+}}^{*} \geq P_{t} \\
\nu \cdot S_{t-1_{+}} \cdot\left(P_{t}-P_{t_{-}}^{*}\right) & \text { if } P_{t-1_{+}}^{*}<P_{t} .
\end{array}\right.
$$

The taxable gain $T_{t_{-}}$and the TLCF $L_{t_{-}}$after realization of $G_{t_{-}}$are then given by

$$
\begin{aligned}
& T_{t_{-}}=\max \left(G_{t_{-}}-L_{t-1_{+}}, 0\right) \\
& L_{t_{-}}=T_{t_{-}}-G_{t_{-}}+L_{t-1_{+}},
\end{aligned}
$$

\footnotetext{
$\overline{5}$ Our way of modeling the realization of capital losses follows Marekwica (2012) and has the desirable feature that we get an upper bound on the investor's basis-price $P_{t_{-}}^{*}$ prior to realization of capital gains exceeding a fraction $\nu$. This upper bound is given by the current market price and allows us to restrict the grid required throughout our numerical solution to investors that are not endowed with unrealized losses before trading at time $t$.
} 
where $L_{t-1_{+}}$is the TLCF after trading at time $t-1$. The investor's tax basis after trading at time $t$ is then given by

$$
P_{t_{+}}^{*}=\frac{S_{t_{-}} \cdot P_{t_{-}}^{*}+\max \left(S_{t_{+}}-S_{t_{-}}, 0\right) \cdot P_{t}}{S_{t_{-}}+\max \left(S_{t_{+}}-S_{t_{-}}, 0\right)} .
$$

The realized gain $G_{t_{+}}$from further trading in the taxable account at time $t$ is given by

$$
G_{t_{+}}=\left(P_{t}-P_{t_{-}}^{*}\right) \cdot \max \left(S_{t_{-}}-S_{t_{+}}, 0\right)
$$

The taxable gain $T_{t_{+}}$and the TLCF $L_{t_{+}}$after realization of further capital gains at time $t$ is given $b^{6}$

$$
\begin{aligned}
& T_{t_{+}}=\max \left(G_{t_{+}}-L_{t_{-}}, 0\right) \\
& L_{t_{+}}=T_{t_{+}}-G_{t_{+}}+L_{t_{-}} .
\end{aligned}
$$

The investor receives non-financial labor income $N_{t}$ of which a constant fraction $k$ is paid directly into a tax-deferred account by the employer. Following Dammon et al. (2004), we assume that the investor does not make any further contributions. When the investor is retired, we do not allow for any contributions and require an investor at age $A_{t}$ with expected remaining life-expectancy of $\mathbb{E}\left[L\left(A_{t}\right)\right]$ to withdraw at least a fraction of $\frac{1}{\mathbb{E}\left[L\left(A_{t}\right)\right]}$ of the remaining tax-deferred wealth when the investor is aged 70.5 and older. Since assets are preferentially held in the tax-deferred account, investors only withdraw when forced by this minimum withdrawal requirement or to finance present consumption.

Given an initial endowment, the investor optimizes the discounted expected utility of lifetime consumption and bequest, subject to the intertemporal budget constraint. Hurd (1989) shows empirically that bequest motives in various countries are very small. We therefore abstract away from a bequest motive. $\beta$ denotes the investor's utility discount factor, $i$ is a constant annual inflation rate, ${ }^{7} M_{t}$ denotes the investor's holdings of money

\footnotetext{
$\overline{6}$ Under current U.S. tax law, investors can offset realized losses of up to $\$ 3,000$ against other income, such as labor income. Given that this amount is not inflation-adjusted and such an opportunity is typically not found under other countries' tax laws, we follow the literature on tax-deferred investing in not explicitly accounting for this small loss offset opportunity.

7 We have to model inflation explicitly through our work to avoid underestimating the impact of the realization-based feature of capital gains taxation on portfolio decisions.
} 
market accounts in the taxable account from time $t$ to $t+1, \alpha_{D, t}$ is the fraction of taxdeferred wealth after contributions and withdrawals held in equity, $g_{t}$ is the pre-tax capital gain on the risky asset from time $t-1$ to time $t, W_{D, t_{-}}\left(W_{D, t_{+}}\right)$is the amount of wealth held in a tax-deferred account before (after) contributions and withdrawals at time $t, W_{T, t}$ is the amount of taxable wealth held in the taxable account at time $t$ before contributions to and withdrawals from the tax-deferred account, and $Z_{t}$ denotes the contribution to or withdrawal from the tax-deferred account at time $t$. The investor's intertemporal consumption-investment problem is

$$
\begin{aligned}
\max _{\left\{C_{t}, M_{t}, S_{t_{+}}, \alpha_{D, t}\right\}_{t=0}^{T}} \mathbb{E}\left[\sum_{t=0}^{T} \beta^{t} \cdot F(t) \cdot U\left(\frac{C_{t}}{(1+i)^{t}}\right)\right] \\
\text { s.t. } \\
W_{D, t_{-}}=W_{D, t_{-} 1_{+}} \cdot\left[\alpha_{D, t-1}\left(1+g_{t}\right)(1+d)+\left(1-\alpha_{D, t-1}\right)(1+r)\right] \\
W_{T, t}=\left(1-\tau_{i}\right) N_{t}+S_{t-1_{+}}\left(1+\left(1-\tau_{d}\right) d\right) P_{t}+M_{t-1}\left(1+\left(1-\tau_{i}\right) r\right)-\tau_{g} T_{t_{-}} \\
W_{D, t_{+}}=W_{D, t_{-}}+Z_{t} \\
W_{T, t}=C_{t}-Z_{t}\left(1-\tau_{i}\right)\left(1-\tau_{p} \chi_{\left\{\left\{A_{t}<J\right\} \cap\left\{Z_{t}<0\right\}\right\}}\right)+M_{t}+S_{t_{+}} P_{t}+\tau_{g} T_{t_{+}} \\
\\
C_{t}>0, S_{t_{+}} \geq 0, M_{t} \geq 0, \alpha_{D, t} \in[0,1]
\end{aligned}
$$

and Equations (9) through (17), where $\chi_{\{x\}}$ is the characteristic function that takes the value one if the event $x$ is true and zero otherwise.

Letting $f(t)$ denote the probability of surviving from time $t$ to $t+1$, the optimization problem can be expressed in a recursive form (Bellman equation) as

$$
V_{t}\left(X_{t}\right)=\max _{C_{t}, M_{t}, S_{t_{+}}, \alpha_{D, t}} f(t) \cdot U\left(\frac{C_{t}}{(1+i)^{t}}\right)+f(t) \cdot \beta \cdot \mathbb{E}_{t}\left[U\left(V_{t+1}\left(X_{t+1}\right)\right)\right]
$$

with the state variables $X_{t}=\left[t, P_{t_{-}}, P_{t_{-}}^{*}, S_{t_{-}}, L_{t_{-}}, W_{T, t}, W_{D, t_{-}}, N_{t}\right]$.

Our optimization problem can be simplified by normalizing both the objective function and the constraints by $W_{t}$ and summarizing information on the level of unrealized gains as a ratio in a single variable. The simplified optimization problem is solved numerically using backward induction. The technical details are outlined in the Appendix. 


\subsection{THE LIMITED USE OF LOSSES AND ASSET LOCATION}

Garlappi and Huang (2006) show in a stylized two-period model that with portfolio constraints in the taxable account, risk averse investors have an incentive to hold mixed portfolios of the risk-free asset and the risky asset in both accounts to smooth the taxadvantage from the tax-exemption of profits in the tax-deferred account through different states. In this section, we proceed in a manner similar to Garlappi and Huang (2006) and demonstrate that the limited use of losses creates another incentive to hold mixed portfolios in both accounts - even when the investor does not face borrowing-and short-selling constraints in the taxable account.

Similar to Garlappi and Huang (2006), in this section, we abstract away from the borrowing-and short-selling constraints, the tax-timing option (i.e., we set $\nu=1$ ), nonfinancial labor income, dividend payments, time preferences (i.e., $\beta=1$ ), and consider a two-period investment horizon. Initially, at time $t=0$, the investor is not endowed with a TLCF from previous trading. Again following Garlappi and Huang (2006), we further assume the investor only derives utility from terminal consumption and abstract away from investor mortality. With the limited use of losses, the Bellman equation can then be written as

$$
\begin{gathered}
V_{1}\left(L_{1}, W_{T, 1}, W_{D, 1_{-}}\right)=\max _{S_{1_{+}}, M_{1}, \alpha_{D, 1}} \mathbb{E}_{1}\left[U \left(S_{1_{+}} P_{2}+M_{1}\left(1+\left(1-\tau_{i}\right) r\right)\right.\right. \\
\left.\left.-\tau_{g} \max \left(S_{1_{+}}\left(P_{2}-P_{1}\right)-L_{1}, 0\right)\right)\right]
\end{gathered}
$$

and

$$
V_{0}\left(W_{T, 0}, W_{D, 0}\right)=\max _{S_{0_{+}}, M_{0}, \alpha_{D, 0}} \mathbb{E}_{0}\left[V_{1}\left(L_{1}, W_{T, 1} W_{D, 1}\right)\right]
$$


Because $\nu=1$, it further holds that $L_{t} \equiv L_{t_{-}}=L_{t_{+}}$. The right-hand side derivative of $V_{1}$ with respect to $L_{1}$ is ${ }^{8}$

$$
\frac{\partial V_{1}}{\partial L_{1}}=\mathbb{E}_{1}\left[\frac{\partial U}{\partial W_{2}^{*}} \cdot\left\{\begin{array}{c}
\tau_{g} \text { if } S_{1_{+}}^{*}\left(P_{2}-P_{1}\right)-L_{1} \geq 0 \\
0 \text { if } S_{1_{+}}^{*}\left(P_{2}-P_{1}\right)-L_{1}<0
\end{array}\right]\right.
$$

where $S_{1_{+}}^{*}$ and

$$
W_{2}^{*}=S_{1_{+}}^{*} P_{2}+M_{1}^{*}\left(1+\left(1-\tau_{i}\right) r\right)-\tau_{g} \max \left(S_{1_{+}}^{*}\left(P_{2}-P_{1}\right)-L_{1}, 0\right)
$$

denote the optimal choice of $S_{1_{+}}$and the wealth level $W_{2}$ implied by optimal choices $S_{1_{+}}^{*}$, $M_{1}^{*}$, and $\alpha_{D, 1}^{*}$ at time $t=1$. The higher $L_{1}$, the higher the likelihood that the marginal value of another marginal unit of TLCF is zero. Hence, the higher the TLCF $L_{1}$ the investor is endowed with from previous trading, the lower the likelihood that it will be used to cover possible gains over the next period and thus, the lower its impact on $V_{1}$. This finding has important implications for the investor's optimal asset location strategy at time $t=0$. Holding everything else equal, from Equation (26), moving equity holdings at time $t=0$ from the taxable to the tax-deferred account is more desirable when the taxable equity exposure is high and the marginal utility from a TLCF $L_{1}$ at time $t=1$ is low.

Consequently, even if moving some equity holdings from the taxable to the tax-deferred account may increase the investor's indirect utility, the implied increased marginal utility of a possible future TLCF implies that the investor eventually reaches the point where it is no longer optimal to move more equity from the taxable to the tax-deferred account. Hence, the changing marginal utility of a possible future TLCF can lead to a violation of the pecking-order asset location rule.

Whereas in the work of Garlappi and Huang (2006), the desire to smooth the volatility of the tax subsidy resulting from the tax-exemption of profits causes an incentive to hold mixed portfolios in both the taxable and the tax-deferred account, the limited use of losses causes yet another incentive for such mixed portfolios. In sections 3 and 4 , we demonstrate

8 The derivative is not defined for $S_{1_{+}}\left(P_{2}-P_{1}\right)-L_{1}=0$. We therefore ask how the indirect utility $V_{1}$ is affected when the TLCF $L_{1}$ increases by a marginal unit, which technically translates into looking at the right-hand side derivative. 
that for reasonable parameter assumptions, these two incentives can cause investors to hold mixed portfolios in both the taxable and the tax-deferred account.

\subsection{BASE CASE PARAMETERS}

Throughout, we consider an investor who makes decisions annually starting at age 20 $(t=0)$. The maximum age the investor can attain is set to 100 years $(T=80)$. It is assumed that the relative risk-aversion of the investor is $\gamma=5$, which is in the range of values considered reasonable by Mehra and Prescott (1985). The annual subjective utility discount factor is $\beta=0.96$. Annual inflation is set to $i=3.2 \%$. The pre-tax return on the risk-free money market account investment is set to $r=4.1 \%$. The expected return on the equity mutual fund is $\mu=8.1 \%$, its standard deviation is $\sigma=19.6 \%$ and the pre-tax dividend rate is $d=2 \%$. This choice of parameters is in line with historical values as reported in Dimson et al. (2002). Estimating the equity premium has been the subject of much theoretical and empirical research (see, e.g., Siegel (2005) for a survey). While the historical U.S. equity premium is around 7.7\% (Dimson et al., 2002), economists doubt whether this will be true in future periods. We therefore choose a somewhat lower equity premium that roughly corresponds to that of the world index as reported in Dimson et al. (2002). We assume that the tax rate on capital gains is $\tau_{g}=20 \%$. Dividends as well as interest and other income is taxed at a rate of $\tau_{d}=\tau_{i}=35 \% .{ }^{9}$ The penalty tax for early withdrawals from tax-deferred accounts prior to retirement age is set to $\tau_{p}=10 \%$ as under current U.S. tax law.

Mandatory retirement age is $J=65$. To keep our model numerically tractable, we follow Dammon et al. (2004) and assume that non-financial labor income $N_{t}$ is a constant multiple of wealth. Labor income is typically a regular stream of positive cash flows and can be viewed as a coupon-bearing bond with stochastic coupon payments. Labor income therefore has an effect on the asset allocation decision (Cocco et al., 2005). More generally, the asset allocation decision heavily reflects an individual's desired risk-versus-return

9 This parameterization is also in line with the historical observation that dividends and interest payments are taxed at higher rates than long-term capital gains (Sialm, 2009). In unreported comparative statics, we allow for different tax rates on dividends and interest. These results are available from the authors. 
tradeoff. For that purpose, potentially pre-existing risk factors, such as labor income risk, are important. The asset location decision on the other hand, is primarily driven by the goal of tax-optimizing an investment strategy. For tax-optimizing purposes, however, the exact modeling of an individual's labor income stream should not have a first-order effect. We assume that non-financial labor income is $n=15 \%$ of effective wealth $W_{t}^{E}$, which we define as wealth that effectively belongs to the investor and on which fiscal authorities do not have a claim: $W_{t}^{E}=W_{t}-\tau_{g} \max \left(S_{t_{-}}\left(P_{t_{-}}-P_{t_{-}}^{*}\right)-L_{t_{-}}, 0\right)$. That is, $N_{t}=0.15 \cdot W_{t}^{E}$. We adjust for potential unrealized gains to avoid an economically implausible link between non-financial income and the realization of capital gains. During retirement we assume that non-financial income drops to $10.5 \%$ of her effective wealth, corresponding to a replacement ratio of $\lambda=70 \%$, which is in the range of replacement ratios empirically estimated by Cocco et al. (2005). During the accumulation phase until retirement age $J$, the employer contribution is set to $k=10 \%$ of the investor's labor income, roughly corresponding to the average contribution reported in Huberman et al. (2007). Survival probabilities are set to the survival probabilities for female investors according to the 2001 Commissioners Standard Ordinary Mortality Table. Table I summarizes our choice of base case parameters.

\section{Numerical Results with Mark-to-Market Taxation}

\subsection{STRUCTURE OF OPTIMAL PORTFOLIOS}

We begin our numerical analysis by studying the structure of optimal portfolios. Specifically, our goal is to illustrate how the limited use of losses impacts optimal asset location decisions. We begin the discussion of our results in a setting with mark-to-market taxation, i.e. a setting where $\nu=100 \%$. Throughout, we report the optimal equity exposures $\alpha_{T, t}^{*}=\frac{S_{t_{+}} P_{t}}{S_{t_{+}} P_{t}+M_{t}}$ and $\alpha_{D, t}$ as fractions of taxable and tax-deferred wealth invested.

Figure 1 depicts the optimal taxable (left graphs) and taxable equity exposures (right graphs) for an investor who trades in a tax system with the full use of losses (Panel A) or the limited use of losses (Panel B) as a function of the investor's age and the 


\section{Table I}

\section{Base case parameter choice}

\begin{tabular}{lcr}
\hline Description & Parameter & Value \\
\hline Pre-tax interest on risk-free money market & $r$ & $4.1 \%$ \\
Pre-tax dividend rate & $d$ & $2 \%$ \\
Pre-tax expected capital gain on equity mutual fund & $\mu$ & $8.1 \%$ \\
Pre-tax standard deviation on capital gain equity mutual fund & $\sigma$ & $19.6 \%$ \\
Inflation rate & $i$ & $3.2 \%$ \\
Capital gains rate & $\tau_{g}$ & $20 \%$ \\
Tax-rate on dividends & $\tau_{d}$ & $35 \%$ \\
Tax-rate on interest and other income & $\tau_{i}$ & $35 \%$ \\
Penalty tax on early withdrawal & $\tau_{p}$ & $10 \%$ \\
Utility discount factor & $\beta$ & 0.96 \\
Degree of risk aversion & $\gamma$ & 5 \\
Maximum length of investment horizon & $T$ & 80 \\
Non-financial income to effective wealth ratio & $n$ & $15 \%$ \\
Retirement contribution rate & $k$ & $10 \%$ \\
Replacement ratio & $\lambda$ & $70 \%$ \\
Mandatory retirement age & $J$ & 65 \\
\hline
\end{tabular}

This table summarizes the parameters used in our model and their base-case values.

fraction of wealth held in a tax-deferred account. For the setting with the limited use of losses, we consider an investor who is not endowed with a tax loss from previous trading. The top panel of Figure 1 confirms the classical finding of Black (1980), Tepper (1981), Dammon et al. (2004) and Huang (2008) and documents that an investor trading in a tax system with the full use of losses optimally follows a strict pecking-order asset location rule and prefers holding equity in taxable and money market mutual funds in tax-deferred accounts. With the full use of losses the investor prefers holding the asset that is subject to the highest tax rate in the tax-deferred account. In general, such an asset location strategy maximizes the investor's expected benefits resulting from the tax exemption of profits in tax-deferred accounts. Investors trading under the full use of losses prefer holding even the most tax-inefficient mutual funds in taxable accounts.

The bottom panel demonstrates that explicitly acknowledging the limited use of losses found in many tax laws around the world has an overwhelming impact on the optimal location of assets to taxable and tax-deferred accounts. In fact, the optimal location is reversed. Whereas with the full use of losses the investor follows a pecking-order asset 
Panel A: Full use of losses

Panel B: Limited use of losses

Figure 1: This figure shows optimal equity exposures in taxable $\left(\alpha_{T, t}^{*}\right)$ and tax-deferred accounts $\left(\alpha_{D, t}\right)$ as functions of age and the fraction of wealth held in a tax-deferred account (Tax-deferred wealth (\%)) for an investor trading in a tax-system with the full use of losses (Panel A) of the limited use of losses (Panel B) who is not endowed with tax loss from previous trading. Tax rates on capital gains, dividends, as well as interest and other income are given by $\tau_{g}=20 \%, \tau_{d}=35 \%$, and $\tau_{i}=35 \%$, respectively. The left graphs show the optimal taxable equity exposure, $\alpha_{T, t}^{*}$. The right graphs show the optimal tax-deferred equity exposure, $\alpha_{D, t}$. It is assumed that $\nu=100 \%$.

location rule that preferentially locates equity mutual funds in taxable accounts, with the limited use of losses the investor preferentially holds equity in tax-deferred accounts.

This rather extreme result is entirely driven by the change in the taxable treatment of realized losses in assets held in taxable accounts. Whereas with the full use of losses, 
the investor gets an immediate tax rebate payment of $\tau_{g}$ times the realized loss, with the limited use of losses the investor is not compensated in cash, but only receives a tax loss carry-forward that can be used to offset future realized gains. As already mentioned above, a tax loss is a less attractive compensation than an immediate tax rebate payment because it cannot be consumed or invested. Furthermore, it carries a risk of never being used and thus being forfeited. In particular, our risk averse investor gets the tax rebate payment when it is most valuable to her, i.e. in situations where she faces a loss on her equity investments. That is, with the full use of losses, capital gain taxation does not only reduce the mutual fund's expected return but also its after-tax downside risks in that fiscal authorities share these risks with the investor. ${ }^{10}$

With the limited use of losses, however, the investor bears the entire immediate downside risk and because optimal portfolios are not changing dramatically over time, realized losses are typically not used for an extended period of time. As a consequence, the risk-return profile of equity mutual funds held in taxable accounts gets substantially less attractive. Specifically, tax authorities still put a tax burden on capital gains held in taxable accounts where they do not grant tax rebate payments on capital losses, but instead only provide the investor with a less desirable tax loss carry-forward. Our results show that this less attractive tax treatment causes the investor to optimally shift the preferred location of the equity mutual fund to the tax-deferred account where she still faces the full downside risk, but at the same time does not have to share capital gains with tax authorities. If, however, investors are endowed with a TLCF from previous periods, the ability to take advantage of the TLCF increases the incentive to hold equity in the taxable account.

\subsection{OPTIMAL CONSUMPTION-INVESTMENT STRATEGIES OVER THE LIFE CYCLE}

Examining optimal state-dependent portfolio decisions is useful in understanding the conditional differences between optimal asset location strategies for an investor trading in a

10 Domar and Musgrave (1944) show that this risk sharing implied by the full use of losses can result in the paradox that the demand for a risky asset increases as the tax burden on its return increases. 
tax system with full and limited use of losses. However, such an analysis does not indicate how likely it is that the investor ends up in a specific state. In this section, we therefore study the impact of the limited versus the full use of losses over the life cycle by performing Monte Carlo simulations on our numerically optimized grid. More specifically, we perform 10,000 simulations over the life cycle. We assume that the investor is neither endowed with unrealized capital gains nor with a tax loss from previous trading at age 20. We report optimal consumption, equity exposures in taxable and tax-deferred accounts, tax losses and the fraction of wealth held in a tax-deferred account conditional on survival.

Confirming the intuition from Figure 1, Table II shows that an investor trading in a tax system with the limited use of losses follow asset location strategies that are diametrically opposed to those of an investor trading in a tax system with the full use of losses. With the limited use of losses, the preferred location for equity mutual funds is the taxdeferred account whereas with the full use of losses they are preferentially held in taxable environments.

Whereas the optimal consumption policy is hardly influenced by the limited use of losses, Table II shows that the allocation of wealth to taxable and tax-deferred accounts is essentially reversed. With the full use of losses the investor prefers holding equity mutual funds in taxable accounts, with the limited use of losses, the equity mutual fund is preferentially held in the tax-deferred account. The preference for equity in tax-deferred environments in tax systems with the limited use of losses implies that tax-deferred wealth on average grows at a stronger rate due to the equity premium the investor on average earns.

In total, our results presented in this section can help understanding why many private investors hold equity in their tax-deferred accounts. However, assuming mark-to-market taxation ignores the tax-timing option and thus potentially overestimates the impact of the limited use of losses. Furthermore, our results cannot explain why some investors prefer equity in taxable environments, whereas others hold mixed portfolios in both taxable and tax-deferred accounts. In section 4 we therefore demonstrate that the optimal location of equity mutual funds to taxable and tax-deferred accounts heavily depends on the tax- 


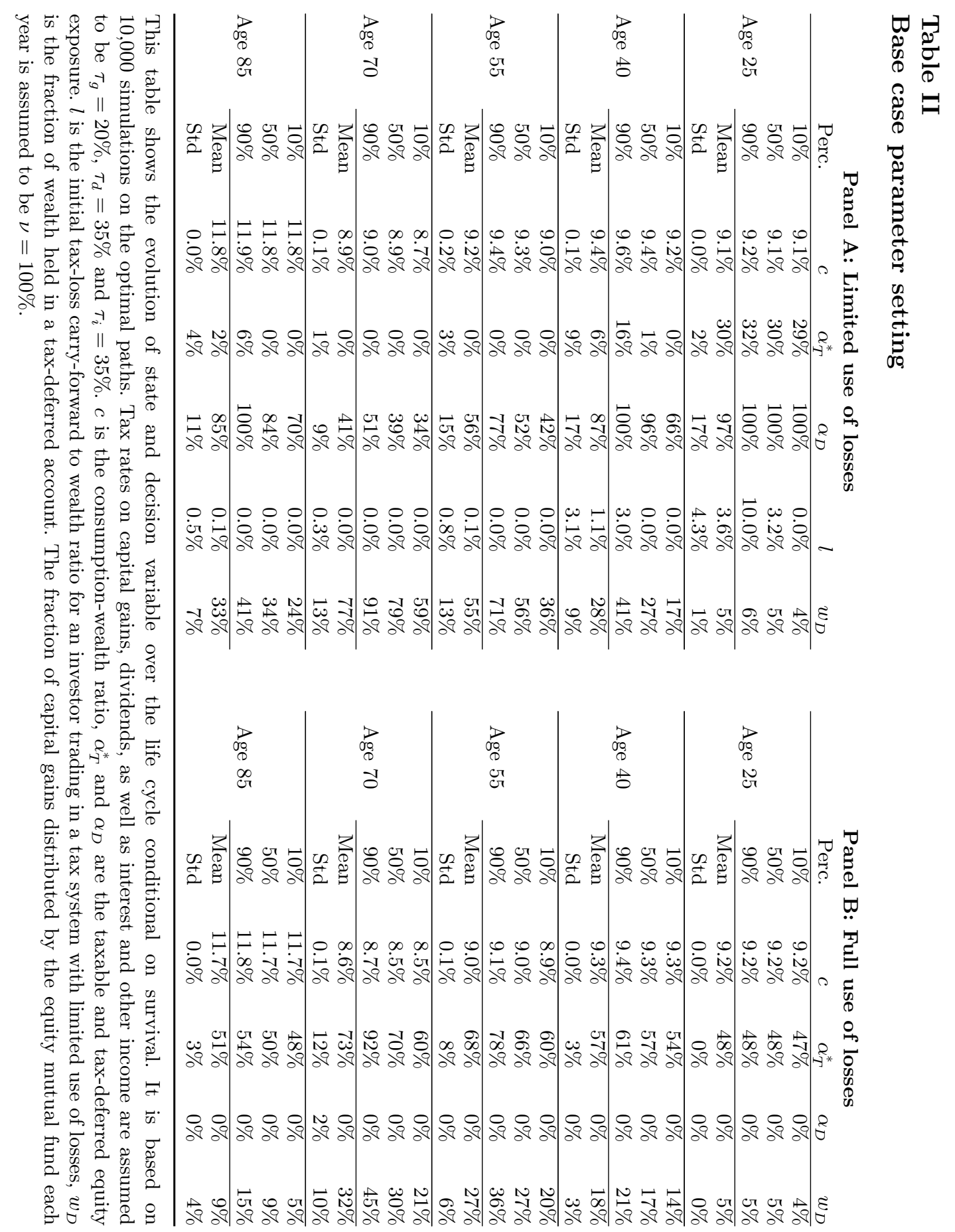


efficiency, $\nu$, of the mutual fund's trading strategy. In particular, an investor trading a tax-efficient mutual fund should preferentially hold it in a taxable account, whereas an investor trading a tax-inefficient mutual fund should prefer holding it in a tax-deferred account. For intermediate levels of a mutual fund's tax-efficiency, we confirm the intuition from section 2.5 that it can be rational to hold mixed portfolios in both accounts.

\section{Numerical Results with a Tax-Timing Option}

Our results in section 3 show that with the full use of losses, the investor should follow a strict pecking order asset location rule and preferentially hold equity mutual funds in taxable accounts. With the limited use of losses and mark-to-market taxation, equity mutual funds are preferentially held in tax-deferred environments. However, many tax codes around the world first tax capital gains when they are realized, thus providing investors with a tax-timing option. In particular, this option makes holding equity mutual funds in taxable environments more attractive as it essentially reduces the effective capital gains rate.

We next turn to the case where $\nu=0$, i.e., where investors can fully exploit the taxtiming option. From Table III, the tax-timing option does not affect optimal asset location decisions with the full use of losses. With the limited use of losses, however, the optimal asset location decision is heavily altered. With mark-to-market taxation $(\nu=1)$, investors prefer holding the mutual fund in the tax-deferred account. While when able to fully exploit the tax-timing option $(\nu=0)$, they prefer holding equity mutual funds in taxable environments.

The cases with mark-to-market taxation $(\nu=1)$ and the opportunity to fully exploit the tax-timing option $(\nu=0)$ illustrate that the exact tax treatment of capital gains is of crucial importance for optimal asset location decisions when the limited use of losses applies. However, neither of the two cases realistically models the tax consequences of capital gains on the mutual fund level for an investor in a realistic fashion.

Neither are equity mutual funds' capital gains taxable on a mark-to-market basis, nor do mutual funds allow investors to fully exploit the tax-timing option. Instead, capital gains 


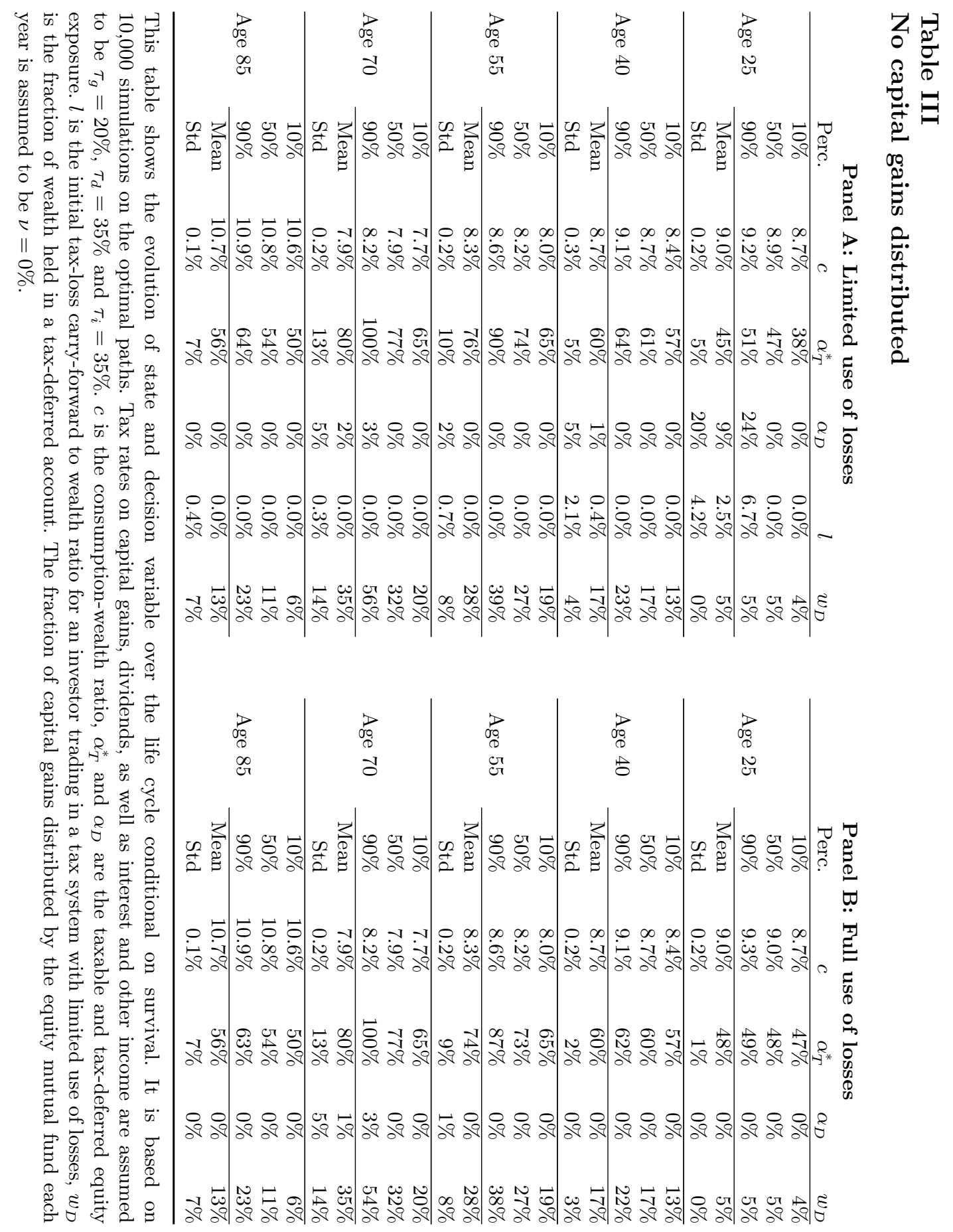


realized due to trading on the mutual fund level are immediately subject to taxation, whereas unrealized capital gains are not taxable until they are realized. In other words, the extent to which investors can benefit from the tax-timing option depends crucially on the tax-efficiency of an equity mutual fund's trading strategy.

The importance of the tax-efficiency of equity mutual funds for optimal asset location strategies has already been pointed out in a setting with the full use of losses and taxexempt municipal bonds as an asset class by Shoven and Sialm (2003). In the following, we show that even in the absence of tax-exempt municipal bonds as an asset class, the optimal location depends on the tax-efficiency of the equity mutual fund when the investor trades in a tax system with the limited use of losses.

We estimate the tax-efficiency, $\nu$, of equity mutual funds using data from the WRDS Mutual Fund Database from 1961 to 2009. Initially, we remove observations with missing values in net asset value (nav_latest) or its lagged value. We consider a fund an equity mutual fund, if it on average holds at least $95 \%$ of its wealth invested in common (per_com) or preferred stocks (per_pref) and remove funds with lower average equity exposures from our sample. To avoid having individual years with potentially above- or below-average capital gains under- or overrepresented, we eliminate funds from our sample for which data is only available for a subperiod. Following Shoven and Sialm (2003), we estimate the average fraction of capital gains distributed by equity mutual funds in two steps. First, we compute the average fraction of capital gains distributed for each equity mutual fund separately by dividing the average annual amount of distributed capital gain per dollar invested by the average annual total capital gain per dollar invested. In a second step, we compute the average fraction $\nu$ of capital gains distributed by equity mutual funds as the mean of the average fraction of capital gains distributed by the mutual funds in our sample. This procedure leaves us with an estimate of $\nu=72 \%$, which is very close to that of Shoven and Sialm (2003) of $\frac{4.3+46.8}{4.3+46.8+18.8}=73.1 \%$ for their average over their Top 5 mutual funds. ${ }^{11}$

As already noted by Shoven and Sialm (2003), the tax-efficiency of equity mutual funds differs significantly between individual funds. In addition to studying the impact

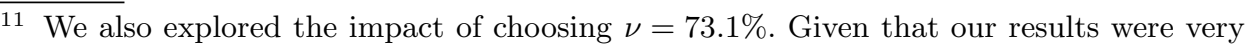
similar to those reported here for $\nu=72 \%$, we did not additionally report them. 
of a fraction of $\nu=72 \%$ of capital gains being distributed annually, we therefore also consider a mutual fund which follows a trading strategy with above-average tax-efficiency. Specifically, we follow Shoven and Sialm (2003) and consider the Vanguard S\&P 500 index fund, which seeks to track the S\&P 500 index and is therefore less engaged in active trading. The Vanguard S\&P 500 index fund was launched in September 1976. We estimate the average fraction of gains realized for the full calendar years from 1977 to 2009 to be $\nu=12 \%$, which is only a fifth of our estimate for the average equity mutual fund estimated above. Again, our estimate is of a similar order of magnitude as the estimate of $\frac{0.4+11.1}{0.4+11.1+67.5}=14.6 \%$ reported by Shoven and Sialm (2003). However, tax-efficient index mutual funds still tend to be relatively rare. Cremers et al. (2016) estimate that the percentage of total net assets held by index funds is only $27 \%$ in the U.S. and $13 \%$ for non-U.S. countries.

Table IV summarizes in a similar manner as Tables II and III the evolution of state and decision variables over the life cycle for an investor trading an equity mutual fund that distributes a fraction $\nu=72 \%$ of unrealized gains, corresponding to the average fraction of gains distributed by U.S. equity mutual funds between 1961 and 2009. Investors trading such funds should optimally hold the mutual fund in a tax-deferred account due to its relatively tax-inefficient trading strategy.

Overall, a comparison between our results in Tables II and IV shows that neither with full nor with limited use of losses optimal consumption-investment strategies are much affected by whether all capital gains are subject to mark-to-market taxation $(\nu=100 \%)$ or the investor trades an equity mutual fund with average tax-efficiency that distributes $\nu=72 \%$ of its unrealized capital gains each year. In total, an investor that trades an equity mutual fund that follows a trading strategy with average tax-(in)efficiency generally prefers holding this equity mutual fund in a tax-deferred account.

In Table $\mathrm{V}$ we show results for an investor trading a tax-efficient equity mutual fund, annually distributing an average fraction of $\nu=12 \%$, corresponding the the average fraction of gains realized by the Vanguard S\&P 500 index fund, of its unrealized gains. ${ }^{12}$ Our results indicate that the optimal location of such a relatively tax-efficient equity mutual

$\overline{12 \text { Sialm }}$ and Zhang (2015) provide empirical evidence that more tax-efficient funds do not underperform other funds before taxes. 


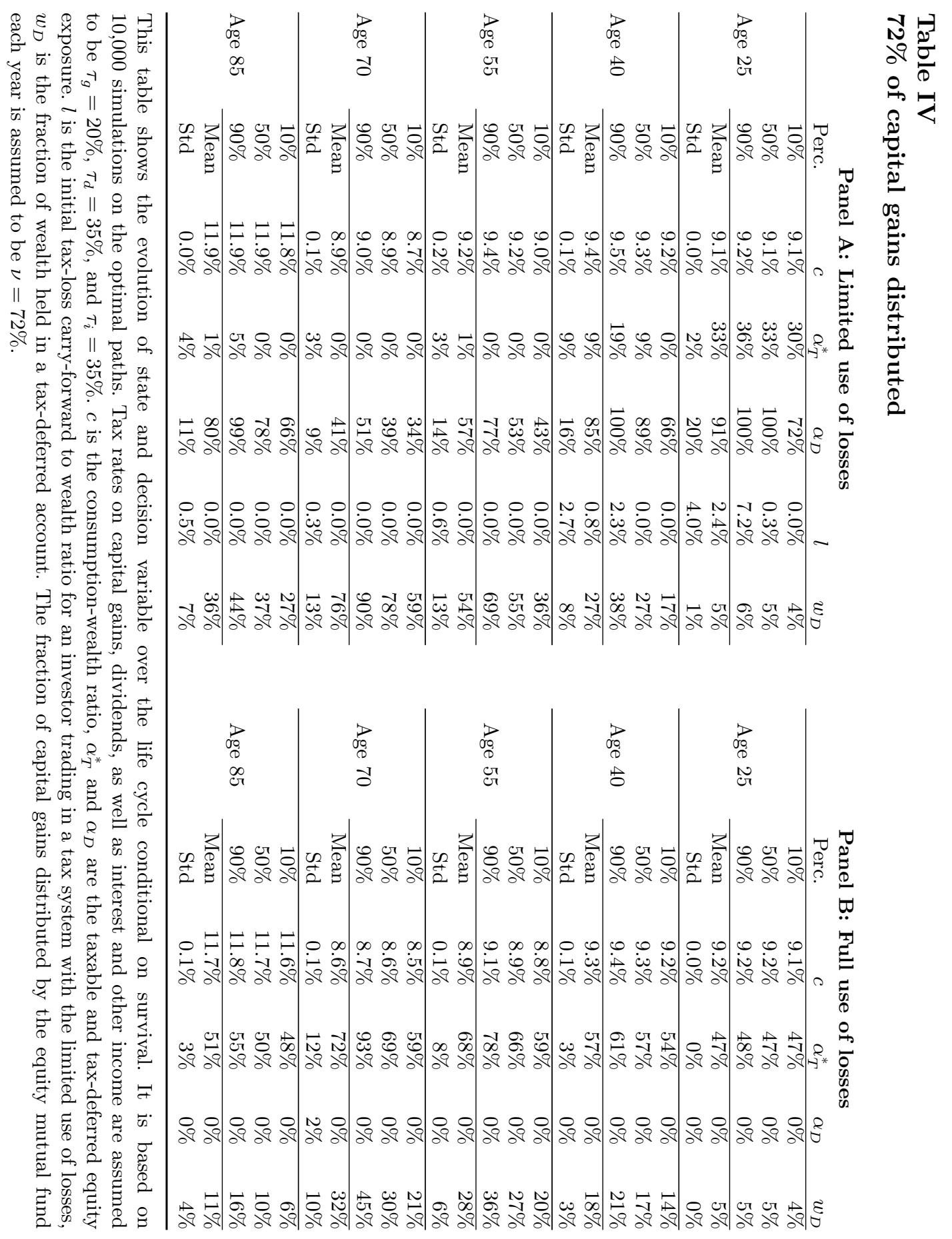




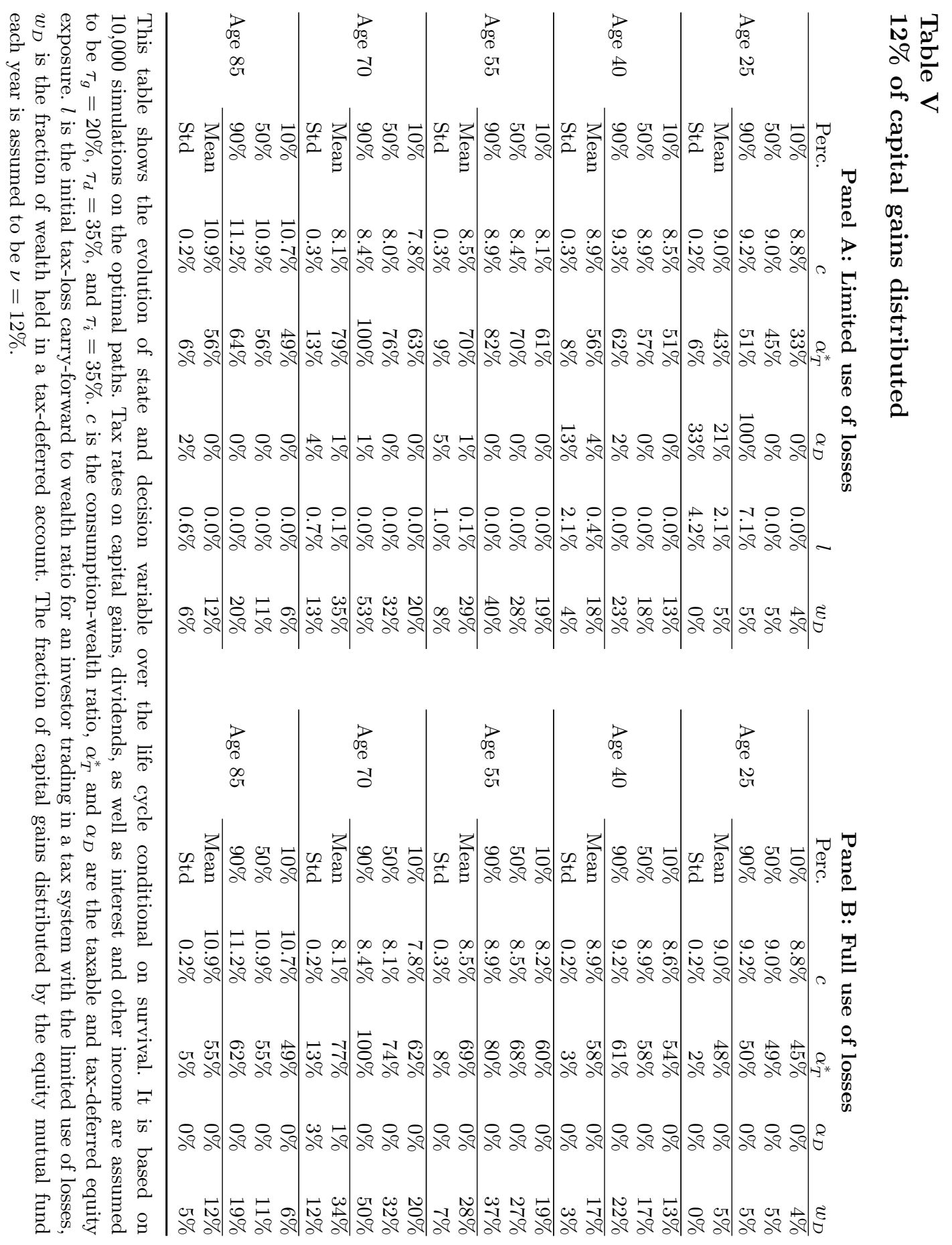


fund is the taxable account - both in tax-systems with full and limited use of losses. Hence, with full use of losses the optimal location for equity mutual funds is the taxable account irrespective of the fund's tax-efficiency. With the limited use of losses, however, the optimal location of assets depends on the tax-efficiency of the equity mutual fund.

We now turn to demonstrating how intermediate values for the fraction of capital gains distributed can cause private investors to optimally hold mixed portfolios in both taxable and tax-deferred accounts. Studying below-average levels of tax-efficiency seems important in light of the evidence in Sialm and Starks (2012) who show that mutual funds primarily held by taxable investors are more tax efficient that funds primarily held in tax-deferred environments.

Table VI shows the impact of different levels of $\nu$ on optimal asset location strategies over the life cycle. Panels A, B, and C show results for an investor trading an equity mutual fund with tax-efficiency of $\nu=30 \%, \nu=40 \%$, and $\nu=50 \%$, respectively. In contrast to our results in Tables IV and V, our results indicate that for these intermediate levels of tax-efficiency, it is optimal to hold mixed portfolios in both the taxable and the taxdeferred account. That is, intermediate levels of the tax-efficiency can rationalize why some investors hold mixed portfolios in both their taxable and tax-deferred accounts.

Simultaneously, the tax-efficiency of the equity mutual fund determines to which extent the incentive to smooth the tax subsidy is traded off against tax and risk-return concerns. ${ }^{13}$ The smoothing incentive seems to be strongest at $\nu=40 \%$ whereas for $\nu=30 \%$ the desire to exploit the tax-timing option tilts the investor's asset location towards holding more equity in taxable environments. For $\nu=50 \%$ on the other hand, the different tax treatment of realized gains and losses favors holding more equity in the tax-deferred account. At the age of 55 for example, the optimal average equity exposure in the taxable account drops from $50 \%$ for $\nu=30 \%$ over $33 \%$ for $\nu=40 \%$ to $4 \%$ for $\nu=50 \%$. Simultaneously, the

$\overline{13}$ Besides the level of $\nu$, the optimal asset location strategy also depends on the relation between the tax rates on capital gains, dividends and interest. If all these three sources of profits are subject to the same tax rate as e.g. under several European tax laws, the investor has an even stronger incentive to hold equity mutual funds in tax-deferred accounts and the level of $\nu$ that makes her hold mixed portfolios in both types of accounts is an order of magnitude lower. Due to space constraints, we have not depicted these results here in detail, but they are available from the authors upon request. 


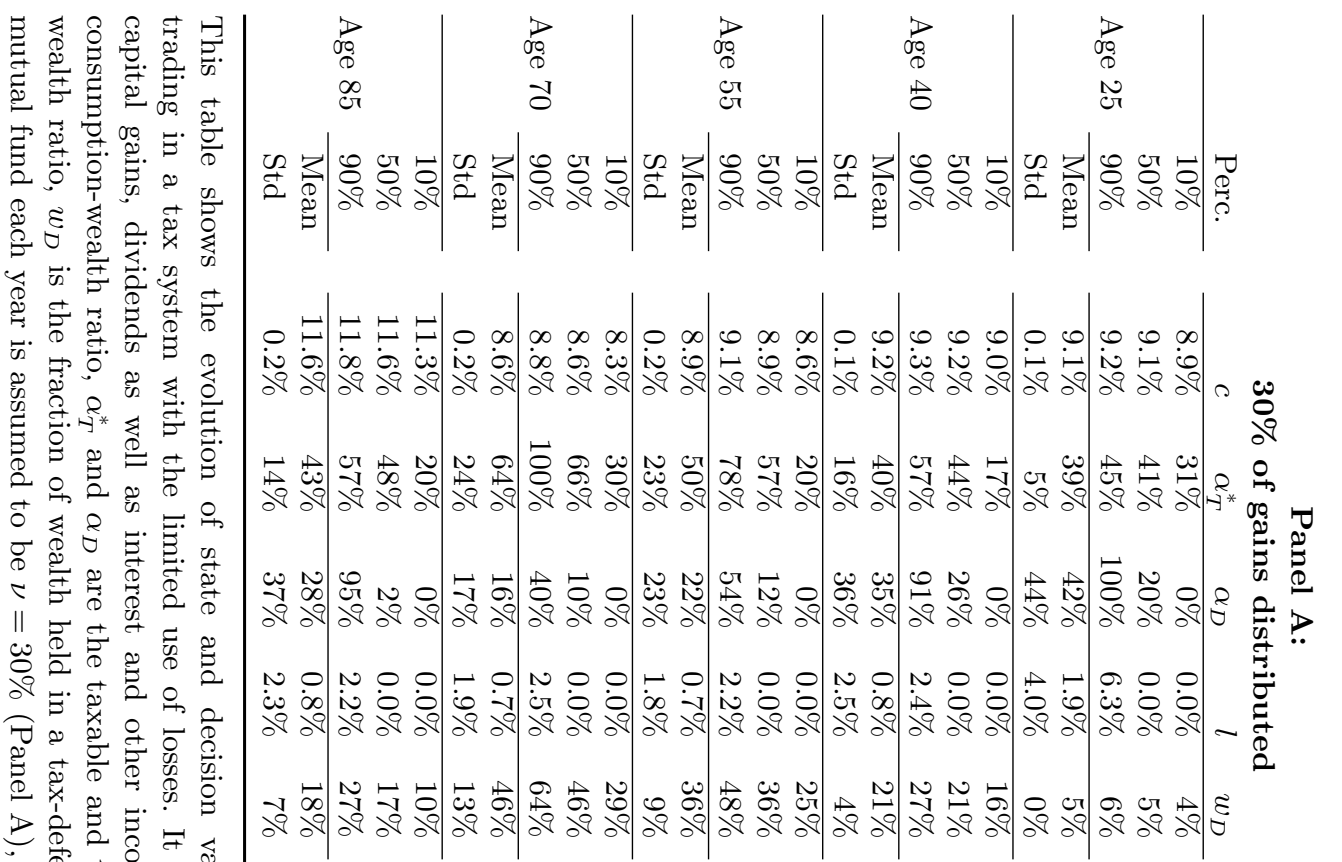

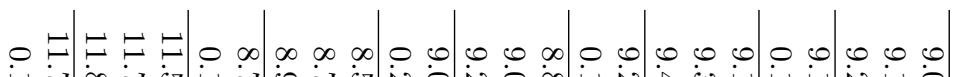

○ी

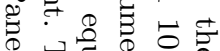

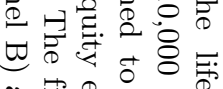

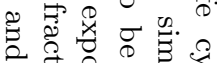

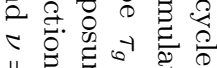
$\|$ I

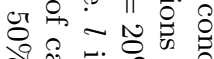
空.

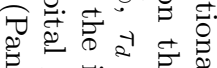

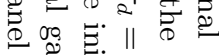
( )

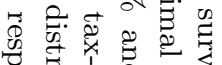

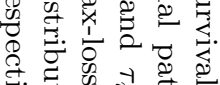

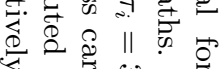

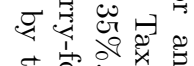

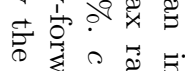

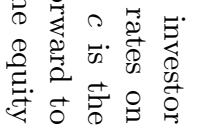

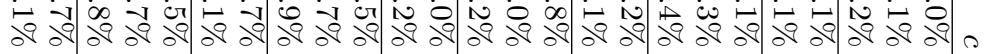

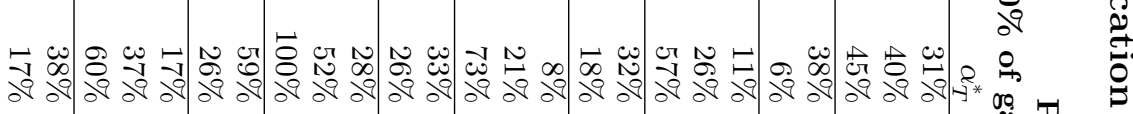

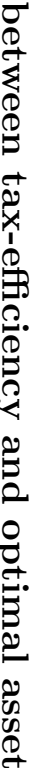

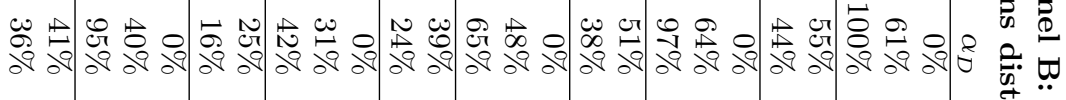

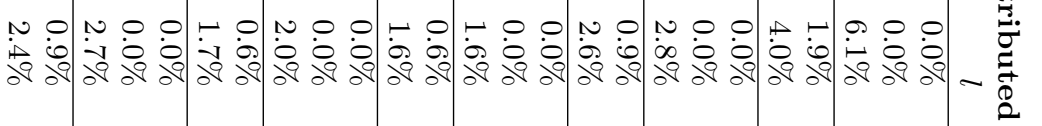

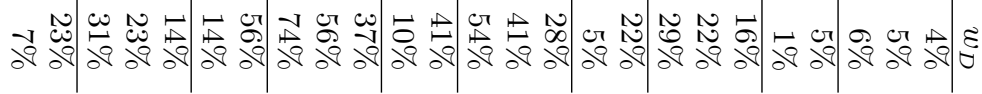

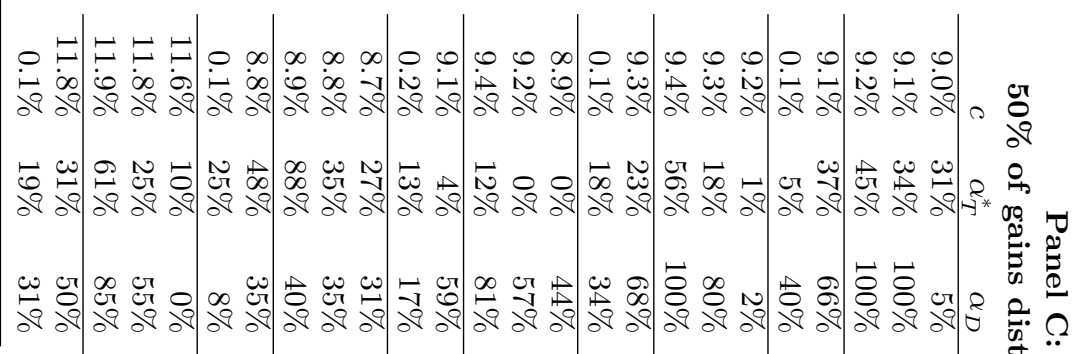

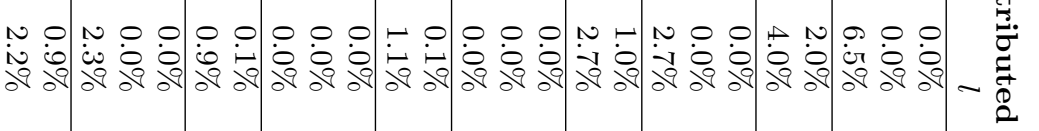

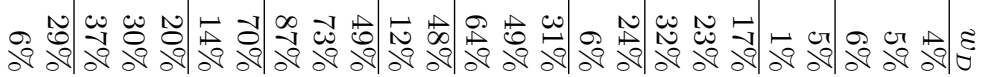


tax-deferred equity exposure increases from $22 \%(\nu=30 \%)$ over $39 \%(\nu=40 \%)$ to $59 \%$ $(\nu=50 \%)$.

In total, our results in this section show that allowing for the realization-based feature of capital gain taxation increases the complexity of the asset location decision compared to a tax system with mark-to-marked taxation. In particular, the tax-efficiency of different mutual funds' trading strategies can help understanding why holding mixed portfolios in both taxable and tax-deferred accounts can be optimal for U.S. investors.

\section{International Evidence}

Our work makes a normative statement: the limited use of losses breaks the pecking-order asset location rule and can cause investors to hold equity in tax-deferred accounts even if equity is subject to a lower tax burden than bonds. We next want to demonstrate that our model predictions are commensurate with empirically observable investor behavior. Ideally, we would exploit variations in tax codes internationally or over time to document that it is indeed the different tax treatment under the limited use of losses compared to the full use of losses that causes investors to break the pecking order asset location rule.

To exploit such variations, we would have to compare asset location strategies of investors trading under the limited use of losses with investors trading under the full use of losses. Unfortunately, the limited use of losses is the standard used in tax codes around the world. The lack of countries that are or have been operating under the full use of losses thus regrettably renders such a direct test impossible. The full use of losses is essentially a popular simplification that is used in scientific research due to its tractability.

To nevertheless demonstrate our model's ability to match empirically observable asset location decisions of individual investors outside the U.S., we calibrate our model with top tax rates of European countries. In addition to the levels of the tax rates, the European tax system differs from its U.S. counterpart along another dimension that is important for our analysis: under European tax law, investors typically are only subject to capital gains taxes on their mutual fund investments when trading their mutual fund shares. Capital gains realized from trading on the mutual fund level are not passed through. That is, 
under European tax law, the taxation of mutual fund shares corresponds to that of stocks and $\nu=0$.

We compare our model's predictions with empirical evidence from the Eurosystem Household Finance and Consumption Survey (HFCS) data that was recently published by the European Central Bank. We focus on households that have private retirement plans/accounts and provide information about their savings. ${ }^{14}$ We do so in the four Eurozone countries, where we have data on more than 1,000 households each. These countries are the four Eurozone countries with the largest populations: Germany, France, Italy, and Spain.

We compute a lower bound on the share of taxable wealth held in equity for each country by dividing the total market value of the individuals' holdings publicly traded shares (data item HD1510) plus the market value of their equity mutual funds (data item HD1320a) by the households' total taxable wealth (sum of data items HD1110, HD1210, HD1320a to HD1320f or HD1320g where available, HD1420, HD1510, HD1620, HD1710, and HD1920) in the respective country. The HFCS data does not contain any information about the share of equity held in mixed mutual funds or managed accounts. By treating them as not investing in equity, our share of taxable wealth held in equity, $\alpha_{T}^{* L}$, provides a lower bound on the taxable equity exposure in the respective country.

In contrast to the U.S., where tax-deferred wealth is identified by being held in a taxdeferred account, in Europe, tax-deferred wealth is identified by being part of a qualified retirement plan. The HFCS data on the composition of households' tax-deferred wealth inside such retirement plans is less detailed than on the taxable level and only distinguishes between whole life insurance and personal voluntary pension plans (data items PF0910a and PF0910b, respectively). If a household has both, the HFCS core variables gathered in all Eurozone countries only allow us to identify the total amount of voluntary pension savings in whole life insurance and personal voluntary pension plans in total. They do not allow us to identify the exact amounts held in the two types. For France, Italy, and Spain,

14 Technically, we require households to have a private pension plan (data item PF0900=1) and to provide information about it (data items PF0910a, PF0910b, and PF0920 not empty, data items PF0910a and PF0910b not both 2 and reported values for total retirement savings (PF0920) correspond to the sum of their components). 
data on the exact value of money in voluntary pension plans is available in separate noncore variables (data item PNF300 $\$ \mathrm{X}$ ) that, unfortunately, are not available for Germany. To compute an upper bound on the share of voluntary retirement savings held in whole life insurance in Germany, we compute an upper bound on the share of tax-deferred wealth in whole life insurance by considering the voluntary retirement savings of households with both whole life insurance (data item PF0910b=1) and a voluntary pension plan (data item PF0910a=1) as fully invested in whole life insurance, respectively. The assets backing up whole life insurance that determine its holders' payoffs typically mainly consist of longterm bonds. The equity share is typically very low. We make a careful estimate and assume the equity share not to exceed $10 \%$.

To determine the equity share in voluntary pension plans, we note that such pension plans typically either invest in qualified pension mutual funds or are held in qualified bank accounts with a fixed interest rate. Because our goal is to compute an upper bound on the share of tax-deferred wealth held in equity, we treat the voluntary pension plan wealth as fully invested into qualified pension mutual funds. Data on the average equity share in these funds is obtained from the data underlying Figure 10 in the OECD report "Pension Markets in Focus" (OECD, 2015). The report does not provide data for France. To determine the upper bound for the share of tax-defereed wealth held in equity in France, we therefore set the average equity share for French pension mutual funds to $100 \%$. The upper bound on the share of tax-deferred wealth held in equity is then computed as

$$
\alpha_{D}^{U}=\theta \cdot 10 \%+(1-\theta) \cdot M F_{E},
$$

where $M F_{E}$ is the country's average equity share in pension mutual funds and $\theta$ is the share of voluntary pension savings in whole life insurance. ${ }^{15}$

Table VII summarizes our results. The first column (model prediction) depicts our model's prediction for the optimal asset location strategy, the last two columns provide our lower bound on the average taxable equity holdings $\left(\alpha_{T}^{* L}\right)$ and the upper bound on the tax-deferred equity holdings $\left(\alpha_{D}^{U}\right)$. Even though we have been very conservative in determining our lower and upper bound for the taxable and tax-deferred equity expo$\overline{15}$ For Germany, where $M F_{E}<10 \%, \theta$ is the upper bound on the share of retirement wealth in whole life insurance. 
Table VII

Asset location - international evidence

\begin{tabular}{llllc}
\hline Country & \multicolumn{2}{c}{ Model prediction } & & \multicolumn{2}{c}{ Empirical evidence } & Number of \\
\cline { 5 - 6 } & & $\alpha_{T}^{* L}$ & $\alpha_{D}^{U}$ & observations \\
\hline Germany & Equity preferred in TA & 14.3 & 10.0 & 1,155 \\
France & Equity preferred in TA & 44.6 & 12.8 & 5,581 \\
Italy & Equity preferred in TA & 12.4 & 13.6 & 1,294 \\
Spain & Equity preferred in TA & 35.7 & 10.6 & 1,722 \\
\hline
\end{tabular}

This table provides international evidence on asset location in the the four Eurozone countries with the largest number of inhabitants (Germany, France, Italy, and Spain) using the Eurosystem Household Finance and Consumption Survey data. The first column (model prediction) depicts our model's prediction for the optimal asset location strategy, the last two columns provide a lower bound on the average taxable equity holdings $\left(\alpha_{T}^{* L}\right)$ and an upper bound on the tax-deferred equity holdings $\left(\alpha_{D}^{U}\right)$ as a share of total taxable and tax-deferred wealth, respectively.

sures of European households, our results show that in line with our model predictions, households in Germany, France, and Spain hold significantly larger equity shares in their taxable accounts. For Italy, our results are somewhat less conclusive. Our lower bound on the taxable equity holdings is slightly below our upper bound on the tax-deferred equity holdings, which may either indicate that Italian households do not behave as predicted by our model or reflect that we have been very conservative in computing the lower bound on the taxable equity exposure and the upper bound on the tax-deferred equity exposure. Overall, our results in this section suggest that our model is able to correctly predict asset location strategies in Europe.

\section{Conclusion}

In this paper, we analyze the optimal dynamic asset allocation and location problem for investors that have access to both taxable and tax-deferred accounts. In line with many tax codes around the world, we allow for a different tax treatment of realized capital gains and losses in taxable accounts. Whereas realized capital gains in such accounts are subject to capital gains taxes, realized capital losses do not leave investors with immediate tax rebate payments. Instead, these losses only provide them with a tax loss carry-forward that can be used to offset future capital gains. 
We show that whereas with the full use of losses equity mutual funds should generally be held in taxable accounts, with the limited use of losses optimal asset location depends on the relative tax burden on different asset classes as well as the tax-efficiency of the mutual fund's trading strategy. In particular, we contribute to existing literature on taxdeferred investing by showing that the limited use of losses can heavily impact optimal asset location strategies.

The limited use of losses can break the classical result of Black (1980), Tepper (1981), and Huang (2008) that investors should preferentially hold equity in taxable accounts. Our work thereby contributes to the stream of literature trying to explain the gap between the asset location strategies suggested in these papers and empirically documented investment behavior of private investors. Furthermore, generalizing Shoven and Sialm (2003), we show that the tax-efficiency of equity mutual funds is not only affecting asset location decisions for investors trading in tax systems with the full use of losses having access to tax-exempt bonds, it also heavily affects asset location decisions for investors that do not have access to tax-exempt assets when taking the limited use of losses into account. Specifically, we argue that tax-efficient equity mutual funds are preferentially held in taxable accounts whereas equity mutual funds with trading strategies of average tax-(in)efficiency are preferentially held in tax-deferred accounts.

An interesting avenue for future empirical research is to explore to which extent private investors take the tax-efficiency of equity mutual funds in their asset location decisions into account. However, such evidence should be inherently difficult to produce, because these effects appear on individual investor level, thus requiring detailed information on the behavior of individual investors and the motives behind their investment activities.

\section{Appendix - Solution of Optimization Problem}

We simplify our optimization problem by (1) normalizing with total wealth, $W_{t}=W_{T, t}+$ $W_{D, t_{-}}\left(1-\tau_{i}\right)$, that effectively belongs to the investor and does not fall to tax authorities upon withdrawal, (2) expressing the level of unrealized capital gains per unit of equity as a basis-to-price ratio, and (3) exploiting that the investor's non-financial income is a 
constant fraction of her effective wealth level. Let $w_{D, t_{-}}=\frac{W_{D, t_{-}}\left(1-\tau_{i}\right)}{W_{t}}$ be the investor's fraction of wealth held in the tax-deferred account after the employer's contribution to or mandatory withdrawals from the tax-deferred account at time $t$, but prior to further voluntary withdrawals, $c_{t}=\frac{C_{t}}{W_{t}}$ be the investor's consumption-wealth ratio in period $t$, $n_{t}=\frac{N_{t}}{W_{t}}\left(1-\tau_{i}\right)$ be the investor's after-tax non-financial income to wealth ratio at time $t, m_{t}=\frac{M_{t}}{W_{T, t}}$ be the fraction of taxable wealth allocated to the money market account at time $t, \alpha_{T, t}=\frac{S_{t_{+}} P_{t}}{W_{T, t}}$ be the fraction of taxable wealth held in equity after trading at time $t, s_{t_{-}}=\frac{S_{t_{-}} P_{t}}{W_{T, t}}$ be the fraction of taxable wealth held in equity after realizing losses and a fraction $\nu$ of unrealized gains but prior to further trading, $p_{t_{-}}^{*}=\frac{P_{t_{-}}^{*}}{P_{t}}$ be the basis-price ratio after realization of losses and a fraction $\nu$ of the investor's unrealized gains, and $l_{t_{-}}=\frac{L_{t_{-}}}{W_{t}}$ be the initial tax loss carry-forward to wealth ratio after realization of losses and a fraction $\nu$ of unrealized gains but prior to further trading.

Then the gross nominal return on the investor's taxable portfolio from time $t$ to $t+1$ after payment of dividends, interest, realization of losses and realization of a fraction $\nu$ of unrealized capital gains at time $t$ is given by

$$
\mu_{T, t+1}=\frac{\alpha_{T, t}\left(1+\left(1-\tau_{d}\right) d\right)\left(1+g_{t+1}\right)+m_{t}\left(1+\left(1-\tau_{i}\right) r\right)-\tau_{g} t_{t+1_{-}}}{\alpha_{T, t}+m_{t}}
$$

where $t_{t+1_{-}}=\frac{T_{t+1}}{W_{T, t+1}}$. The gross rate of return on the investor's tax-deferred portfolio from time $t$ to $t+1$ is given by

$$
\mu_{D, t+1}=\alpha_{D, t}(1+d)\left(1+g_{t+1}\right)+\left(1-\alpha_{D, t}\right)(1+r)
$$

The dynamic wealth equation is then given by

$$
W_{t+1}=W_{t}\left[\left(1-w_{D, t_{+}}\right)\left(\alpha_{T, t}+m_{t}\right) \mu_{T, t+1}+w_{D, t_{+}} \mu_{D, t+1}\right] \cdot \frac{1}{1-n_{t+1}}
$$

where $w_{D, t_{+}}=\frac{W_{D, t_{+}}\left(1-\tau_{i}\right)}{W_{t}}$.

The assumption of constant relative risk-aversion and the linearity of the dynamic wealth equation imply that our decision variables $c_{t}, \alpha_{T, t}$, and $\alpha_{D, t}$ are independent of the investor's wealth level. With the above transformations, the relevant state variables for the optimization problem become $x_{t}=\left\{t, s_{t_{-}}, p_{t_{-}}^{*}, w_{D, t_{-}}, l_{t_{-}}\right\}$. Defining $v_{t}\left(x_{t}\right)=$ 
$\left(\frac{V_{t}\left(X_{t}\right)}{W_{t}(1+i)^{t}}\right)^{1-\gamma}$ as the investor's normalized value function and $\rho_{t+1}=\frac{W_{t+1}}{W_{t}(1+i)}$ as the real gross growth of wealth from time $t$ to $t+1$, the normalized problem can be expressed as

$$
\begin{aligned}
v_{t}\left(x_{t}\right)= & \max _{\left\{c_{t}, m_{t}, \alpha_{T, t}, \alpha_{D, t}\right\}} f(t) \cdot U\left(c_{t}\right)+f(t) \cdot \beta \cdot \mathbb{E}_{t}\left[v_{t+1}\left(x_{t+1}\right) \rho_{t+1}^{1-\gamma}\right] \\
& \text { s.t. } \\
\rho_{t+1}= & \frac{\left(1-w_{D, t_{+}}\right)\left(\alpha_{T, t}+m_{t}\right) \mu_{T, t+1}+w_{D, t_{+}} \mu_{D, t+1}}{\left(1-n_{t+1}\right)(1+i)} \\
& c_{t}>0, \alpha_{T, t} \geq 0, m_{t} \geq 0, \alpha_{D, t} \in[0,1] .
\end{aligned}
$$

We solve this optimization problem numerically using backward induction. We approximate values lying between our grid points using quad-linear interpolation. The integral of the expectation in Equation (A.4) is computed using Gaussian quadrature. Parallel computing is employed to expedite our computations.

\section{References}

Amromin, G. (2003) Household portfolio choices in taxable and tax-deferred accounts: another puzzle? European Finance Review 7, 547-582.

Bergstresser, D. and Poterba, J. M. (2004) Asset allocation and asset location: household evidence from the survey of consumer finance, Journal of Public Economics 88, 1893-1915. Black, F. (1980) The tax consequences of long-run pension policy, Financial Analysts Journal 36, 21-28.

Cocco, J. F., Gomes, F. J., and Maenhout, P. J. (2005) Consumption and portfolio choice over the life cycle, Review of Financial Studies 18, 491-533.

Constantinides, G. M. (1983) Capital market equilibrium with personal taxes, Econometrica 51, 611-636.

Cremers, M., Ferreira, M., Matos, P., and Starks, L. (2016) Indexing and active fund management: international evidence, Journal of Financial Economics 120, 539-560.

Dammon, R. M., Spatt, C. S., and Zhang, H. H. (2001) Optimal consumption and investment with capital gains taxes, Review of Financial Studies 14, 583-616. 
Dammon, R. M., Spatt, C. S., and Zhang, H. H. (2004) Optimal asset location and allocation with taxable and tax-deferred investing, Journal of Finance 59, 999-1037.

Dammon, R. M., Spatt, C. S., and Zhang, H. H. (2011) Retirement investing: analyzing the 'Roth' conversion and re-characterization options, unpublished working paper, Carnegie Mellon University and University of Texas at Dallas.

DeMiguel, V. and Uppal, R. (2005) Portfolio investment with the exact tax basis via nonlinear programming, Management Science 51, 277-290.

Dimson, E., Marsh, P., and Staunton, M. (2002) Triumph of the optimists: 101 years of global investment returns, Princeton University Press, Princeton.

Domar, E. D. and Musgrave, R. A. (1944) Proportional income taxation and risk-taking, Quarterly Journal of Economics 58, 388-422.

Ehling, P., Gallmeyer, M., Srivastava, S. Tompaidis, S., and Yang, C. (2015) Portfolio tax trading with carry-over losses, unpublished working paper, University of Virginia.

Gallmeyer, M. and Srivastava, S. (2011) Arbitrage and the tax code, Mathematics and Financial Economics 4, 183-221.

Gallmeyer, M. Kaniel, R., and Tompaidis, S. (2006) Tax management strategies with multiple risky assets, Journal of Financial Economics 80, 243-291.

Garlappi, L. and Huang, J. (2006) Are stocks desirable in tax-deferred accounts? Journal of Public Economics 90, 2257-2283.

Gomes, F., Michaelides, A., and Polkovnichenko, V. (2009) Optimal savings with taxable and tax-deferred accounts, Review of Economic Dynamics 12, 718-735.

Huang, J. (2008) Taxable and tax-deferred investing: a tax arbitrage approach, Review of Financial Studies 21, 2173-2207.

Huberman, G., Iyengar, S. S., and Jiang, W. (2007) Defined contribution pension plans: determinants of participation and contribution rates, Journal of Financial Services Research 31, 1-32.

Hurd, M. D. (1989) Mortality risk and bequest, Econometrica 57, 779-813.

Marekwica, M. (2012) Optimal tax-timing and asset allocation when tax rebates on capital losses are limited, Journal of Banking and Finance 36, 2048-2063. 
Mehra, R. and Prescott, E. C. (1985) The equity premium: a puzzle, Journal of Monetary Economics 15, 145-162.

OECD (2015) Pension markets in focus, Technical Report, OECD.

Poterba, J. M. Shoven, J. B., and Sialm, C. (2004) Asset location for retirement savers, in G. Gale, J. Shoven and M. Warshawsky (eds.), Private pensions and public policies, Brooking Institute, Washington, D.C.

Shoven, J. B. and Sialm, C. (1998) Long run asset allocation for retirement savings, Journal of Private Portfolio Management 1, 13-26.

Shoven, J. B. and Sialm, C. (2003) Asset location in tax-deferred and conventional savings accounts, Journal of Public Economics 88, 23-38.

Sialm, C. (2009) Tax changes and asset pricing, American Economic Review 99, 13561383.

Sialm, C. and Starks, L. (2012) Mutual fund tax clienteles, Journal of Finance 67, 13971422 .

Sialm, C. and Zhang, H. (2015) Tax efficient asset management: evidence from equity mutual funds, NBER working paper number 21060.

Siegel, J. J. (2005) Perspectives on the equity risk premium, Financial Analysts Journal 61, 61-73.

Tepper, I. (1981) Taxation and corporate pension policy, Journal of Finance 36, 1-13.

Zhou, J. (2009) The asset location puzzle: taxes matter, Journal of Economic Dynamics and Control 33, 955-969.

Zhou, J. (2012) Life-cycle stock market participation in taxable and tax-deferred accounts, Journal of Economic Dynamics and Control 36, 1814-1829. 